\title{
Spatiotemporal Trends, Sources and Ecological Risks of Heavy Metals in the Surface Sediments of Weitou Bay, China
}

\author{
Qiuming Chen, Faming Huang * and Anran Cai
}

check for

updates

Citation: Chen, Q.; Huang, F.; Cai, A. Spatiotemporal Trends, Sources and Ecological Risks of Heavy Metals in the Surface Sediments of Weitou Bay, China. Int. J. Environ. Res. Public Health 2021, 18, 9562. https:// doi.org/10.3390/ijerph18189562

Academic Editors: Remigio Paradelo Núñez and María Teresa Barral Silva

Received: 4 August 2021

Accepted: 9 September 2021

Published: 10 September 2021

Publisher's Note: MDPI stays neutral with regard to jurisdictional claims in published maps and institutional affiliations.

Copyright: (c) 2021 by the authors. Licensee MDPI, Basel, Switzerland. This article is an open access article distributed under the terms and conditions of the Creative Commons Attribution (CC BY) license (https:// creativecommons.org/licenses/by/ $4.0 /)$.
Third Institute of Oceanography, Ministry of Natural Resources, Xiamen 361005, China; chenqiuming@tio.org.cn (Q.C.); $18060207886 @ 163 . c o m$ (A.C.)

* Correspondence: huangfaming@tio.org.cn; Tel.: +86-592-219-5001

\begin{abstract}
Heavy metals are extremely harmful materials to marine ecosystems and human health. To determine the anthropogenic contributions and ecological risks in Weitou Bay, China, the spatiotemporal variations in the concentrations of heavy metals in surface sediment were investigated during spring 2008 and 2017. The results indicated that high concentrations of pollutants were generally located near the river mouths and along the coast of industrial areas. Principal component analysis indicated that heavy metal contents were mainly affected by industrial waste drainage, urban development, natural weathering and erosion, and interactions between organic matter and sulfides. The potential ecological risk assessment demonstrated that, in $2008,82 \%$ of the sampling sites were at low risk, while $18 \%$ were at moderate risk. The situation had deteriorated slightly by 2017 , with $73 \%, 18 \%$, and $9 \%$ of stations in Waytou Bay at low, moderate, and very high risk, respectively. Cd was the most harmful metal, followed by Hg. These two elements accounted for more than $80 \%$ of the potential ecological risk index $(R I)$ value. The present work analyzed the source of heavy metals, identified the major pollution elements and high risk areas, and provides guidance for pollution control and ecological restoration in Weitou Bay.
\end{abstract}

Keywords: heavy metal; surface sediment; pollution; spatiotemporal variation; ecological risk; source

\section{Introduction}

As regions of active land-sea interactions, coastal areas are considered to be sinks for various contaminants derived from natural source and anthropogenic activities [1]. Along with rapid economic growth in coastal regions, an increasing number of pollutants are discharged into the ocean, leading to serious environmental problems and potential threats to aquatic organisms and marine ecosystems $[2,3]$.

Unlike some organic pollutants, heavy metals do not degrade easily. Due to their persistence, toxicity, bioaccumulation, and non-biodegradability, heavy metals have been acknowledged as extremely harmful materials to marine ecosystems and human health [4,5]. Owing to the effects of adsorption, flocculation, and subsidence, a considerable amount of heavy metal pollutants discharged into seawater are transferred to the sediment, while only a small part remains dissolved in the water [6]. Nevertheless, under complex physicochemical and dynamic conditions, heavy metals can be released from surface sediments into the seawater [7]. Therefore, sediment becomes not only a reservoir for heavy metals in the ocean, but also an indicator of contamination in the marine environment. To a certain extent, the distribution of heavy metals in sediments reflects the pollution level of the marine environment and is commonly used to determine the source(s) of the pollutants [8]. Studying the distributions and pollution status of heavy metals and their controlling mechanisms under the influence of anthropogenic activity provides a basis for pollution control and environmental protection.

Weitou Bay is located in Quanzhou City in Fujian Province, which is an important location of economic growth in southeastern China. From 2008 to 2017, the GDP in Quanzhou increased from 270.5 billion Chinese RMB (CNY) to 754.8 billion, and the 
resident population increased by 900,000 people [9,10]. Along with accelerated industrialization and urbanization during recent decades, an increasing number of factories have been constructed in the coastal area of Weitou Bay, including textile factories, bleaching and dyeing factories, tanneries factories, and electroplating factories. Large quantities of pollutants from land-based sources, including continental runoff, industrial effluent, and domestic wastewater, are released into Weitou Bay and ultimately accumulate in seafloor deposits [11]. Since 2008, environmental protection and restoration measures have been conducted in Weitou Bay, including upstream river regulation, marine aquaculture dredging, and sewage interception, which may improve the quality of the marine environment. In contrast, the rapid industrialization, urbanization, reclamation, and enhancement of the port's throughput capacity have increased pressure on the marine ecosystem.

Some studies of heavy metals in Weitou Bay have been conducted, but these were mainly limited in their spatial distributions, sources, and potential ecological risks [11-13]. Studies of spatiotemporal variations in heavy metals in this area are currently lacking. In order to explore the combined effects of environment protection and increased anthropogenic pressure on the marine environment, we investigated the spatiotemporal variations in heavy metals in the surface sediments of Weitou Bay under complex driving forces over 10 years (in 2008 and 2017).

The main goals of this study included: (1) determining the temporal variations in heavy metals in the surface sediment; (2) determining the spatial distributions of heavy metals; (3) exploring the main sources of heavy metals and analyzing the factors that cause spatiotemporal changes in pollution; (4) assessing the potential ecological risk levels, identifying the main ecological risk factors, and making recommendations for pollution control and ecological restoration in the bay.

\section{Materials and Methods}

\subsection{Study Area}

Weitou Bay is a semi-enclosed bay located in southeastern Fujian Province, China, to the west of the Taiwan Strait (Figure 1), and is the beginning of the ancient Maritime Silk Road in China. The bay is characterized by regular semi-diurnal tides with an average tidal range of $4.19 \mathrm{~m} \mathrm{[14]} \mathrm{and} \mathrm{does} \mathrm{not} \mathrm{freeze,} \mathrm{owing} \mathrm{to} \mathrm{the} \mathrm{subtropical} \mathrm{monsoon} \mathrm{climate} \mathrm{in}$ the region. Weitou Bay is trumpet-shaped, with a narrow northern bay (inner bay) that extends inland. The inner bay has an $800 \mathrm{~m}$ mouth and is approximately $9 \mathrm{~km}$ long, $1.5 \mathrm{~km}$ wide, and covers $13.1 \mathrm{~km}^{2}$, of which $9.8 \mathrm{~km}^{2}$ comprises intertidal flats [13]. The inner bay receives continuous inputs of land-based pollutants from the Daying, Xiadian, and Jiatang Rivers, and the seabed in this area has a high sedimentation rate [11].

The southern part of Weitou Bay (outer bay) has a relatively wider mouth and deeper water depths. The hydrodynamic conditions due to vertical and horizontal mixing gradually increase from the inner bay to the outer bay [8]. The outer bay is $12 \mathrm{~km}$ wide in the $\mathrm{N}-\mathrm{S}$ direction and $22 \mathrm{~km}$ wide in the E-W direction, with an area of $279.9 \mathrm{~km}^{2}$, of which $58.1 \mathrm{~km}^{2}$ is intertidal flats. Two deep grooves $\sim 15 \mathrm{~m}$ in depth are located in the middle of the outer bay $[15,16]$.

Weitou Bay is influenced by human activity (sewage and industrial discharge, harbor activities, reclamation), which have increased its environmental risk, decreased the tidal volume, caused the water to become eutrophic, and resulted in huge amounts of pollutants, including heavy metals being deposited in the sediment. These factors all pose threats to aquatic organisms and the marine ecosystem in the bay $[12,13,17]$.

\subsection{Sampling and Analyses}

Surface sediment $(0-5 \mathrm{~cm})$ samples were collected from Weitou Bay during the spring of 2008 and 2017 using a stainless - steel grab sampler (Figure 1). The samples were then placed into sealed polyethylene bags and stored at $4{ }^{\circ} \mathrm{C}$ until analysis. Total organic carbon (TOC), sulfide, and heavy metal $(\mathrm{Cu}, \mathrm{Pb}, \mathrm{Zn}, \mathrm{Cd}, \mathrm{Cr}, \mathrm{Hg}$, and $\mathrm{As}$ ) concentrations were analyzed following standard Chinese marine monitoring methods (GB 17378.5-2007) [18]. 

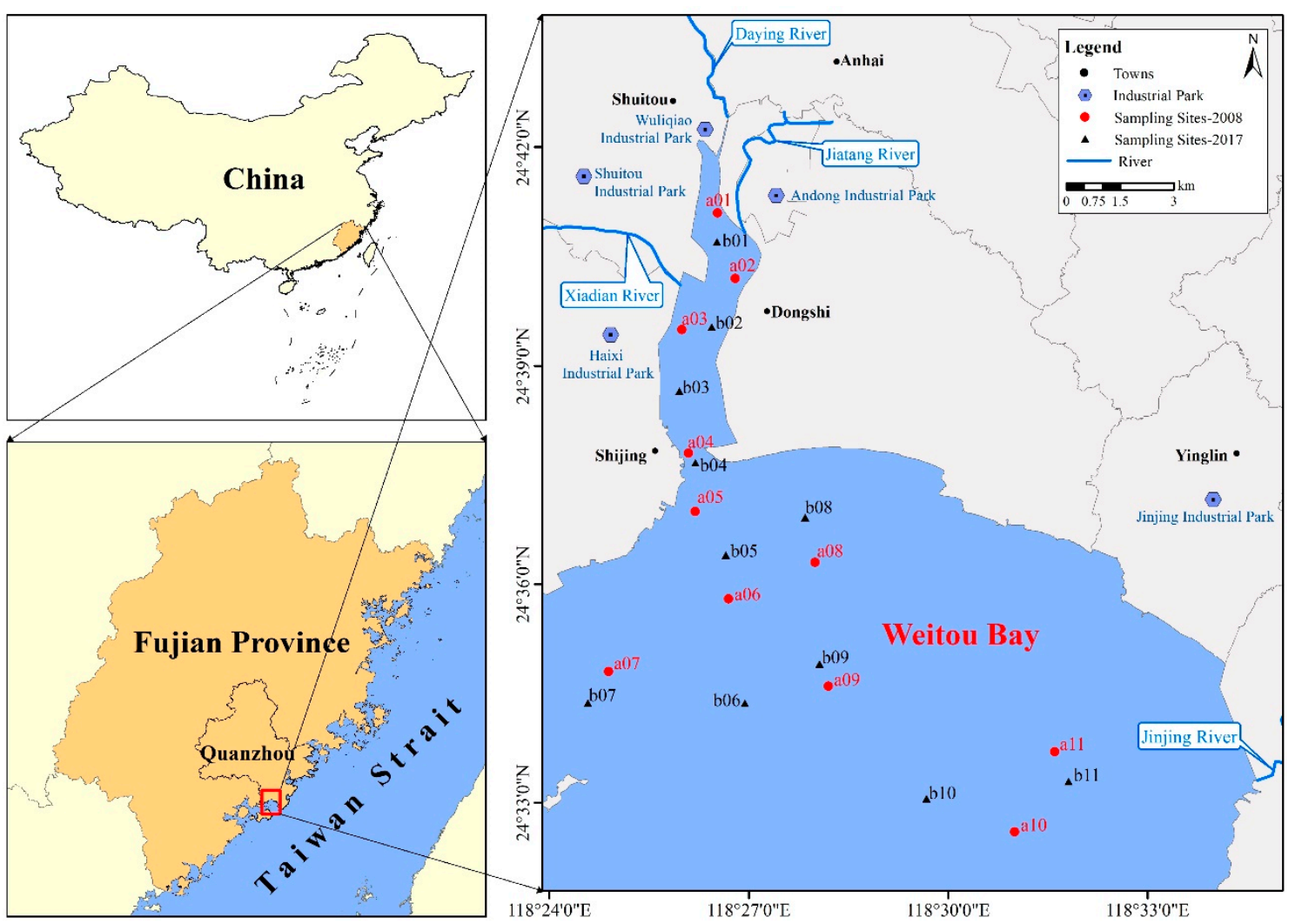

Figure 1. Location of the study area in Weitou Bay, China.

Prior to analysis, the samples were dried at $60^{\circ} \mathrm{C}$, ground to pass through a $160-$ mesh sieve, and fully mixed. To determine the contents of $\mathrm{Cu}, \mathrm{Pb}, \mathrm{Zn}, \mathrm{Cd}$, and $\mathrm{Cr}, 0.1 \mathrm{~g}$ of the dry samples was digested with a solution of $\mathrm{HNO}_{3}+\mathrm{HClO}_{4}+\mathrm{HCl}(6: 2: 1$ by volume) in glass beakers on an electric hotplate for $2 \mathrm{~h}$. The compositions and corresponding concentrations of the digested samples were then analyzed using atomic absorption spectrometry (Jenna Zeenit 6000). For the $\mathrm{Hg}$ and As analyses, $0.1 \mathrm{~g}$ of each sample was digested with chloroazotic acid $\left(\mathrm{HNO}_{3}+\mathrm{HCl}, 3: 1\right.$ by volume $)$ for $2 \mathrm{~h}$, then analyzed using atomic fluorescence spectrometry (AFS-920). TOC concentrations were determined using the potassium dichromate oxidation method [18]. Sulfide concentrations were analyzed using the iodine method [18].

For data quality control, standard reference materials (GBW07314, from the National Research Center for Certified Reference Materials, Beijing, China) were analyzed using the above method, and the recovery rates of the monitoring factors ranged from $95 \%$ to $110 \%$. The determinations had a precision (represented by the average relative standard deviation (RSD) of parallel samples) of better than $5.0 \%$. The quality control measurement results indicated that the determination accuracy met the requirements of this study (an average RSD of parallel samples less than $5 \%$, and recovery rates of the monitoring factors between $90 \sim 110 \%$ [18]).

\subsection{Potential Ecological Risk Assessment of Sediment}

The potential ecological risk index $(R I)$ was used to obtain a comprehensive assessment of ecological pressure from heavy metals. The $R I$ was calculated using the following Equations [19]:

$$
\begin{aligned}
& C_{f}^{i}=C^{i} / C_{n}^{i} \\
& E_{\mathrm{r}}^{i}=T_{\mathrm{r}}^{i} \times C_{f}^{i}
\end{aligned}
$$




$$
R I=\sum_{i=1}^{m} E_{r}^{i}
$$

where $i, f$, and $m$ denote a specific metal $i$ in the sediment sample, fraction, and total number of metals analyzed in the sediment sample, respectively. $C_{f}^{i}$ is the contamination factor for an individual metal. $C^{i}$ is the concentration of metal $i$ in the sample and $C_{n}^{i}$ is the background value for metal $i$. In this study, the heavy metals concentrations in the coastal soil in Fujian Province served as the background values [20] (Table 1). $E_{r}^{i}$ is the potential ecological risk factor for a single heavy metal. $T_{r}^{i}$ is the toxicity factor for heavy metal $i$, representing its toxicity levels and the sensitivity towards bio-organisms. In this study, Hakanson's standard toxicity factors were adopted; the values for the toxicity factors of $\mathrm{Cu}, \mathrm{Pb}, \mathrm{Zn}, \mathrm{Cd}, \mathrm{Cr}, \mathrm{Hg}$, and As are 5, 5, 1, 30, 2, 40, and 10, respectively [19,21].

Table 1. Heavy metal concentrations in the surface sediment of Weitou Bay.

\begin{tabular}{|c|c|c|c|c|c|c|c|c|c|c|}
\hline \multirow{2}{*}{ Year } & \multirow{2}{*}{ Value } & \multirow{2}{*}{$\begin{array}{c}\text { TOC } \\
(\%)\end{array}$} & Sulfide & $\mathrm{Cu}$ & $\mathrm{Pb}$ & $\mathrm{Zn}$ & $\mathrm{Cd}$ & $\mathrm{Cr}$ & $\mathrm{Hg}$ & As \\
\hline & & & \multicolumn{8}{|c|}{$\left(\mathrm{mg} \cdot \mathrm{kg}^{-1}\right)$} \\
\hline \multirow{7}{*}{2008} & Min & 0.35 & 12.4 & 3.5 & 1.8 & 23.4 & 0.016 & 2.61 & 0.017 & 1.30 \\
\hline & Max & 1.84 & 841.0 & 155.0 & 11.9 & 213.0 & 0.384 & 78.40 & 0.060 & 8.50 \\
\hline & Mean-whole & 0.94 & 179.6 & 38.7 & 6.6 & 118.6 & 0.113 & 20.87 & 0.034 & 4.10 \\
\hline & Mean-inner & 1.33 & 361.3 & 73.7 & 9.6 & 149.0 & 0.198 & 38.22 & 0.048 & 5.54 \\
\hline & Mean-outer & 0.62 & 28.2 & 9.5 & 4.2 & 93.3 & 0.043 & 6.41 & 0.022 & 2.93 \\
\hline & SD & 0.46 & 289.0 & 44.9 & 3.8 & 45.2 & 0.113 & 23.08 & 0.015 & 1.90 \\
\hline & RSD & 0.5 & 1.6 & 1.2 & 0.6 & 0.4 & 1.0 & 1.1 & 0.4 & 0.5 \\
\hline \multirow{8}{*}{2017} & Min & 0.29 & 23.5 & 3.1 & 0.1 & 20.8 & 0.123 & 5.20 & 0.012 & 2.10 \\
\hline & Max & 1.24 & 130.5 & 62.8 & 26.3 & 161.0 & 1.180 & 56.30 & 0.054 & 10.00 \\
\hline & Mean-whole & 0.60 & 207.6 & 15.2 & 10.2 & 62.9 & 0.265 & 21.77 & 0.030 & 5.60 \\
\hline & Mean-inner & 0.86 & 171.6 & 25.8 & 7.5 & 85.2 & 0.467 & 15.78 & 0.034 & 6.23 \\
\hline & Mean-outer & 0.46 & 60.4 & 9.13 & 11.8 & 50.1 & 0.150 & 25.19 & 0.029 & 5.27 \\
\hline & $\mathrm{SD}$ & 0.31 & 377.4 & 16.3 & 9.3 & 36.9 & 0.306 & 17.23 & 0.015 & 2.70 \\
\hline & RSD & 0.5 & 1.8 & 1.1 & 0.9 & 0.6 & 1.2 & 0.8 & 0.5 & 0.5 \\
\hline & Background & / & / & 22.4 & 39 & 83.6 & 0.06 & 40.70 & 0.063 & 6.38 \\
\hline
\end{tabular}

Min, max, mean-whole are the minimum, maximum, and average concentrations of the entire Weitou Bay, respectively. Mean-inner and mean-outer are the average concentrations of the inner and outer Weitou Bay, respectively. SD and RSD are the standard deviation and relative standard deviation of the entire Weitou Bay, respectively. Background values are the concentrations of heavy metals in the coastal soils of Fujian Province. "/" indicates no available comparison data.

The $E_{r}^{i}$ and $R I$ values are classified into five and four degrees of ecological risk, respectively. The classifications are as follows: (1) $E_{r}^{i}<40$, low ecological risk; $40<E_{r}^{i}<80$, moderate ecological risk; $80<E_{r}^{i}<160$, considerable ecological risk; $160<E_{r}^{i}<320$, very high ecological risk; $E_{r}^{i} \geq 320$, disastrous ecological risk; (2) RI $<150$, low ecological risk; $150<\mathrm{RI}<300$, moderate ecological risk; $300<\mathrm{RI}<600$, considerable ecological risk; $\mathrm{RI} \geq 600$, very high ecological risk [22].

\subsection{Statistical Analyses}

The SPSS software package (version 20.0) was used to determine the Pearson correlation coefficients of all tested factors, and principal component analysis (PCA) was conducted to explore the potential pollution sources (natural or artificial) and their elemental characteristics. PCA is commonly used to identify potential pollution sources, distinguish natural and anthropogenic contributions, and indicate biogeochemical processes related to heavy metals. In this study, principal components were performed based on the correlation matrix and extracted if their eigenvalues were greater than 1.0. We then used ArcGIS 10.0 (Environmental Systems Research Institute, inc.) with the Kriging spatial interpolation method to quantitatively determine the spatial distributions of the heavy metals. 


\section{Results and Discussion}

\subsection{Spatiotemporal Distributions of Heavy Metals}

3.1.1. Temporal Variations and Trends

The heavy metal concentrations in the Weitou Bay surface sediment are presented in Table 1 and Figure 2. For the seven heavy metals measured in the surface sediments, the mean concentrations of $\mathrm{Cu}$ and $\mathrm{Zn}$ decreased from 2008 to 2017, while the $\mathrm{Cd}, \mathrm{Pb}$, and As concentrations increased and the $\mathrm{Hg}$ and $\mathrm{Cr}$ concentrations did not vary significantly (Figure 2a). Specifically, the mean concentrations and ranges of $\mathrm{Cu}$ and $\mathrm{Zn}$ decreased from $38.7 \mathrm{mg} \cdot \mathrm{kg}^{-1}\left(3.5-155.0 \mathrm{mg} \cdot \mathrm{kg}^{-1}\right)$ and $118.6 \mathrm{mg} \cdot \mathrm{kg}^{-1}\left(23.4-213.0 \mathrm{mg} \cdot \mathrm{kg}^{-1}\right)$ to $15.2 \mathrm{mg} \cdot \mathrm{kg}^{-1}\left(3.1-62.8 \mathrm{mg} \cdot \mathrm{kg}^{-1}\right)$ and $62.9 \mathrm{mg} \cdot \mathrm{kg}^{-1}\left(20.8-161.0 \mathrm{mg} \cdot \mathrm{kg}^{-1}\right)$, respectively. Although the concentrations of $\mathrm{Cd}, \mathrm{Pb}$, and As increased from 2008 to 2017, As concentrations increased less than those of $\mathrm{Cd}$ and $\mathrm{Pb}$. Cd increased $135 \%$ from $0.113 \mathrm{mg} \cdot \mathrm{kg}^{-1}$ $\left(0.016-0.384 \mathrm{mg} \cdot \mathrm{kg}^{-1}\right)$ to $0.265 \mathrm{mg} \mathrm{kg}{ }^{-1}\left(0.123-1.180 \mathrm{mg} \cdot \mathrm{kg}^{-1}\right)$. Pb increased $57 \%$ from $6.6 \mathrm{mg} \cdot \mathrm{kg}^{-1}\left(1.8-11.9 \mathrm{mg} \cdot \mathrm{kg}^{-1}\right)$ to $10.2 \mathrm{mg} \cdot \mathrm{kg}^{-1}\left(0.1-26.3 \mathrm{mg} \cdot \mathrm{kg}^{-1}\right)$. However, As increased $37 \%$ from $4.1 \mathrm{mg} \cdot \mathrm{kg}^{-1}\left(1.3-8.5 \mathrm{mg} \cdot \mathrm{kg}^{-1}\right)$ to $5.6 \mathrm{mg} \cdot \mathrm{kg}^{-1}\left(2.1-10.0 \mathrm{mg} \cdot \mathrm{kg}^{-1}\right)$. In addition, both $\mathrm{Hg}$ and $\mathrm{Cr}$ exhibited small changes from 2008 to 2017. The mean $\mathrm{Hg}$ concentration was $0.034 \mathrm{mg} \cdot \mathrm{kg}^{-1}\left(0.017-0.060 \mathrm{mg} \cdot \mathrm{kg}^{-1}\right)$ in 2008 and $0.030 \mathrm{mg} \cdot \mathrm{kg}^{-1}$ $\left(0.012-0.054 \mathrm{mg} \cdot \mathrm{kg}^{-1}\right)$ in 2017 . Correspondingly, the mean Cr concentration was $20.87 \mathrm{mg} \cdot \mathrm{kg}^{-1}$ $\left(2.61-78.40 \mathrm{mg} \cdot \mathrm{kg}^{-1}\right)$ in 2008 and $21.77 \mathrm{mg} \cdot \mathrm{kg}^{-1}\left(5.20-56.30 \mathrm{mg} \cdot \mathrm{kg}^{-1}\right)$ in 2017.
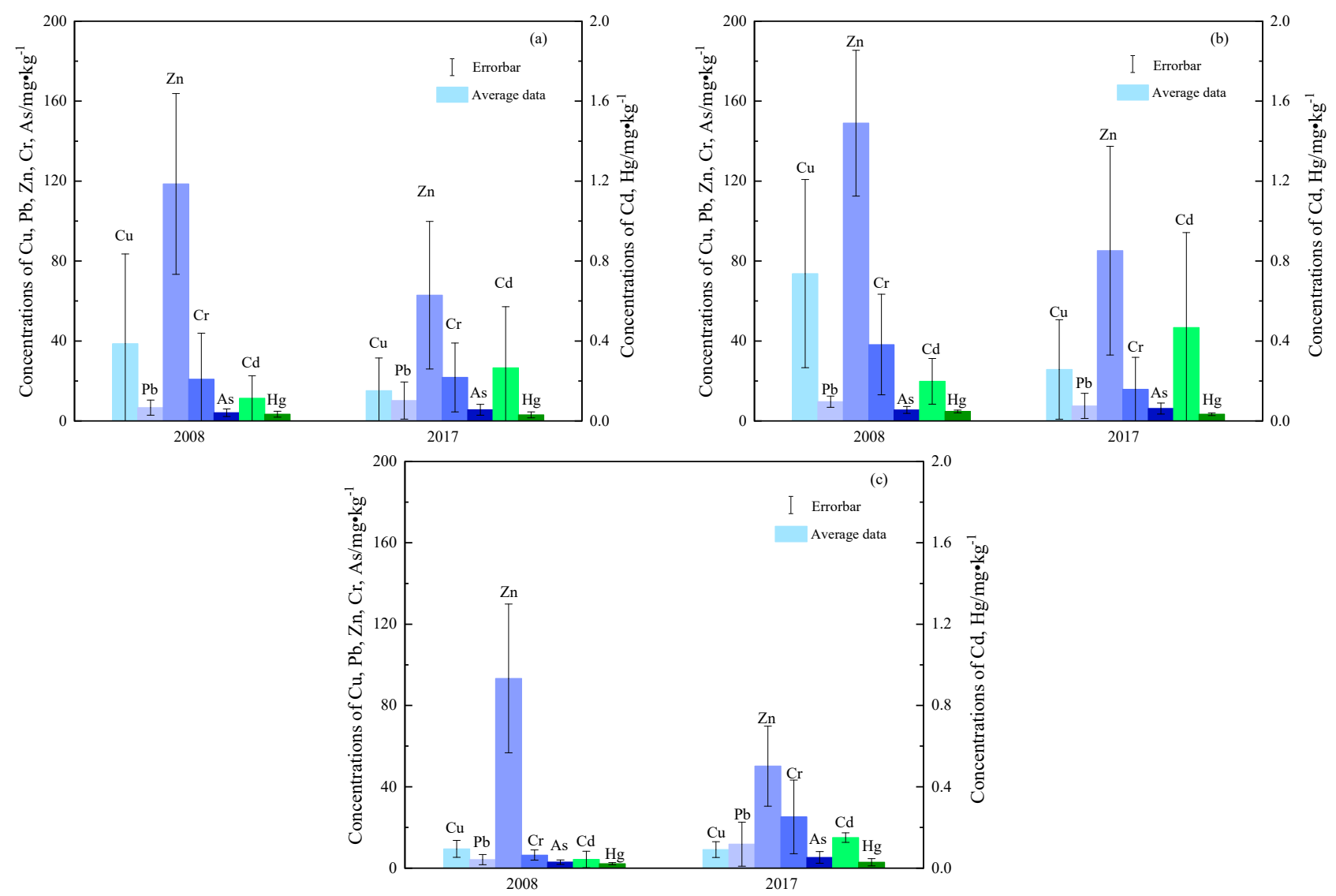

Figure 2. Heavy metal concentrations of the surface sediment from (a) the entire Weitou Bay, (b) inner Weitou Bay, (c) outer Weitou Bay.

It can be judged from the RSD value (Table 1) that the difference in the spatial distribution of $\mathrm{Cu}$ was the most significant among the seven heavy metals, followed by $\mathrm{Cd}$ and $\mathrm{Cr}$, while the difference in the spatial distribution of $\mathrm{Pb}, \mathrm{Zn}, \mathrm{Hg}$, and As was relatively small. On the other hand, as shown in Figure 2, the mean concentrations of heavy metals in the outer bay were lower than those in the inner bay in 2008. In 2017, except for $\mathrm{Pb}$ and $\mathrm{Cr}$, the 
averages of other elements were still lower than those in the inner bay. Overall, the outer bay was less polluted by heavy metals than the inner bay.

The 2008 average concentrations of $\mathrm{Cu}\left(38.7 \mathrm{mg} \cdot \mathrm{kg}^{-1}\right), \mathrm{Zn}\left(118.6 \mathrm{mg} \cdot \mathrm{kg}^{-1}\right)$, and $\mathrm{Cd}$ $\left(0.113 \mathrm{mg} \cdot \mathrm{kg}^{-1}\right)$ in the surface sediments of Weitou Bay were higher than the environmental background values. However, since $\mathrm{Cu}\left(15.2 \mathrm{mg} \cdot \mathrm{kg}^{-1}\right)$ and $\mathrm{Zn}\left(62.9 \mathrm{mg} \cdot \mathrm{kg}^{-1}\right)$ decreased in 2017, only the mean Cd concentration $\left(0.265 \mathrm{mg} \cdot \mathrm{kg}^{-1}\right)$ was higher than the environmental background value. In contrast, in both 2008 and 2017, the mean concentrations of the other heavy metals $(\mathrm{Pb}, \mathrm{Cr}, \mathrm{Hg}$, and $\mathrm{As})$ were below the environmental background values.

\subsubsection{Spatial Distributions of Heavy Metals}

The spatial distributions of heavy metal concentrations are shown in Figure 3. Concentrations of heavy metals in Weitou Bay are related to several factors and are indeed influenced by anthropogenic activity and hydrodynamic conditions. In 2008, the areas with high concentration of all heavy metals in sediment were located in inner Weitou Bay, and the spatial distribution exhibited a decreasing trend from north to south in the bay. In general, higher heavy metal concentrations in the inner bay are caused by large amounts of terrestrial pollution input by the three rivers flowing into the bay and sewage discharges from the coastal industrial zone. In addition, the weak hydrodynamic conditions in the inner bay prevent heavy metals from being diluted rapidly, resulting in their deposition in the sediment. Heavy metals discharged into the inner bay are partially deposited in sediments before they enter the outer bay with tidal currents. This could be one of the reasons why the mean heavy metal concentrations in the outer bay sediment were lower than those in the inner bay.

In 2017, two features of the spatial distribution of heavy metal concentrations were observed, including increasing concentrations in the outer bay and a shift of high concentration from the inner bay to the outer bay. High heavy metal concentrations were observed in the southeastern inshore area of the outer bay, where a new industrial center (including chemical fiber, printing and dyeing, electroplating, and other industries) was built after 2008. In contrast, except for Cd and As, heavy metal concentrations decreased in the inner bay. This improvement can be largely attributed to a series of remediation measures in the inner bay between 2008 and 2017, including upstream river regulation, sewage interception, and the closure of small polluting enterprises. For $\mathrm{Cu}$ and $\mathrm{Zn}$, although the average concentrations decreased in both the inner and outer bay (Figure 2), higher concentrations were observed in the outer bay (Figure 3). $\mathrm{Pb}, \mathrm{Cr}$, and $\mathrm{Hg}$ exhibited similar changes in spatial distribution from 2008 to 2017 (Figure 2), as the average concentrations of these heavy metals decreased in the inner bay but increased in the outer bay. For $\mathrm{Cd}$ and As, overall increases in their average concentrations occurred throughout the bay; however, the rate of increase in the outer bay was much higher than that of the inner bay (Figure 2). From 2008 to 2017, the average Cd concentration increased by $136 \%$ (from $0.198 \mathrm{mg} \cdot \mathrm{kg}^{-1}$ to $0.467 \mathrm{mg} \cdot \mathrm{kg}^{-1}$ ) in the inner bay but increased by $249 \%$ (from $0.043 \mathrm{mg} \cdot \mathrm{kg}^{-1}$ to $0.150 \mathrm{mg} \cdot \mathrm{kg}^{-1}$ ) in the outer bay. Meanwhile, As increased by $12 \%$ in the inner bay and by $80 \%$ in the outer bay.

\subsection{Heavy Metal Sources}

Previous studies have indicated that heavy metals in surface sediment originate from various sources and could be primarily affected by three factors: (1) pollutant emissions from urban development and human activity; (2) adsorption and sequestration with organic matter and sulfide; and (3) natural weathering and erosion of rocks [23-25]. Therefore, correlation analysis and PCA were conducted to explore the relationships between the seven heavy metals, TOC, and sulfide in the surface sediment. 

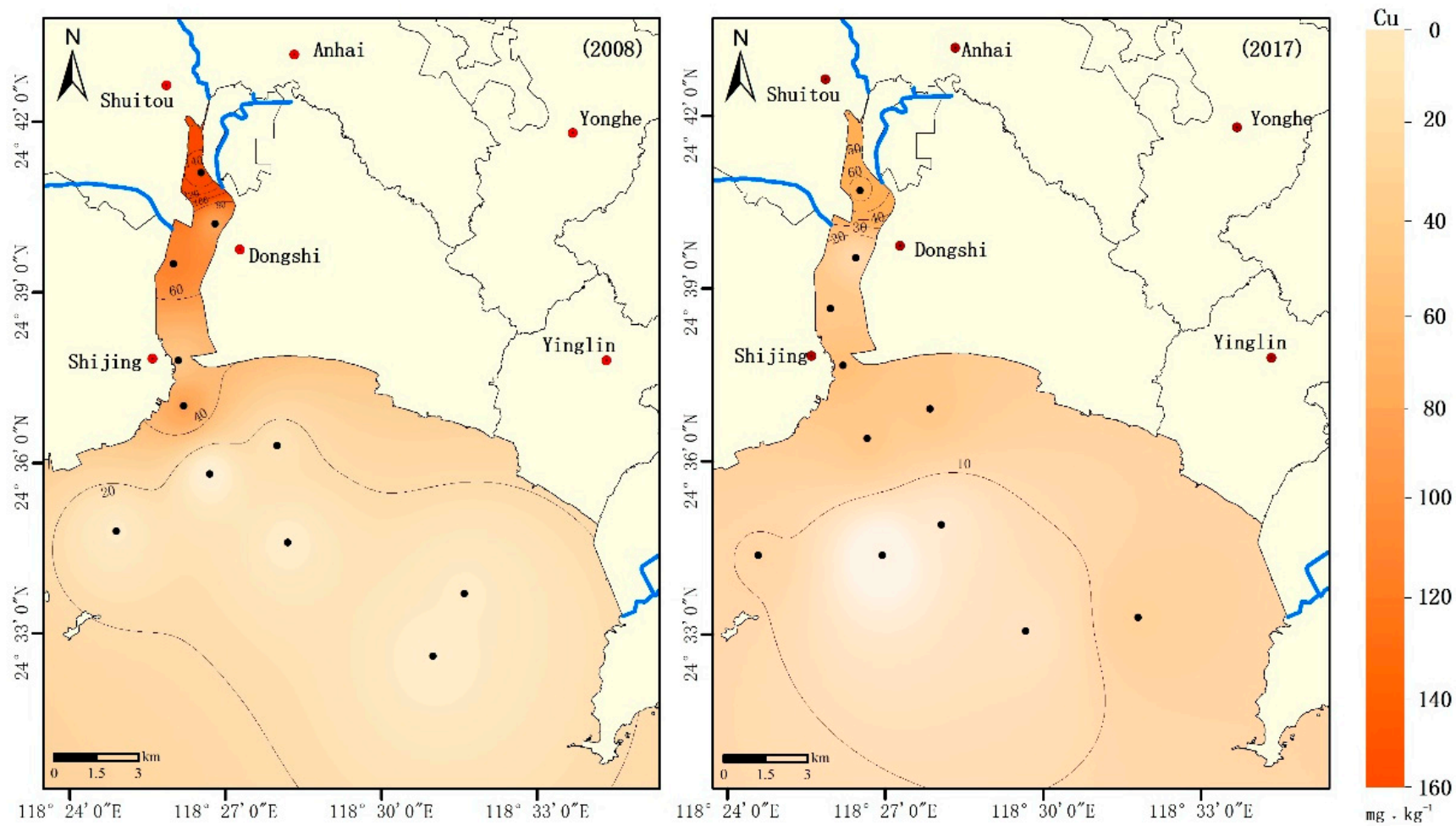

(a)
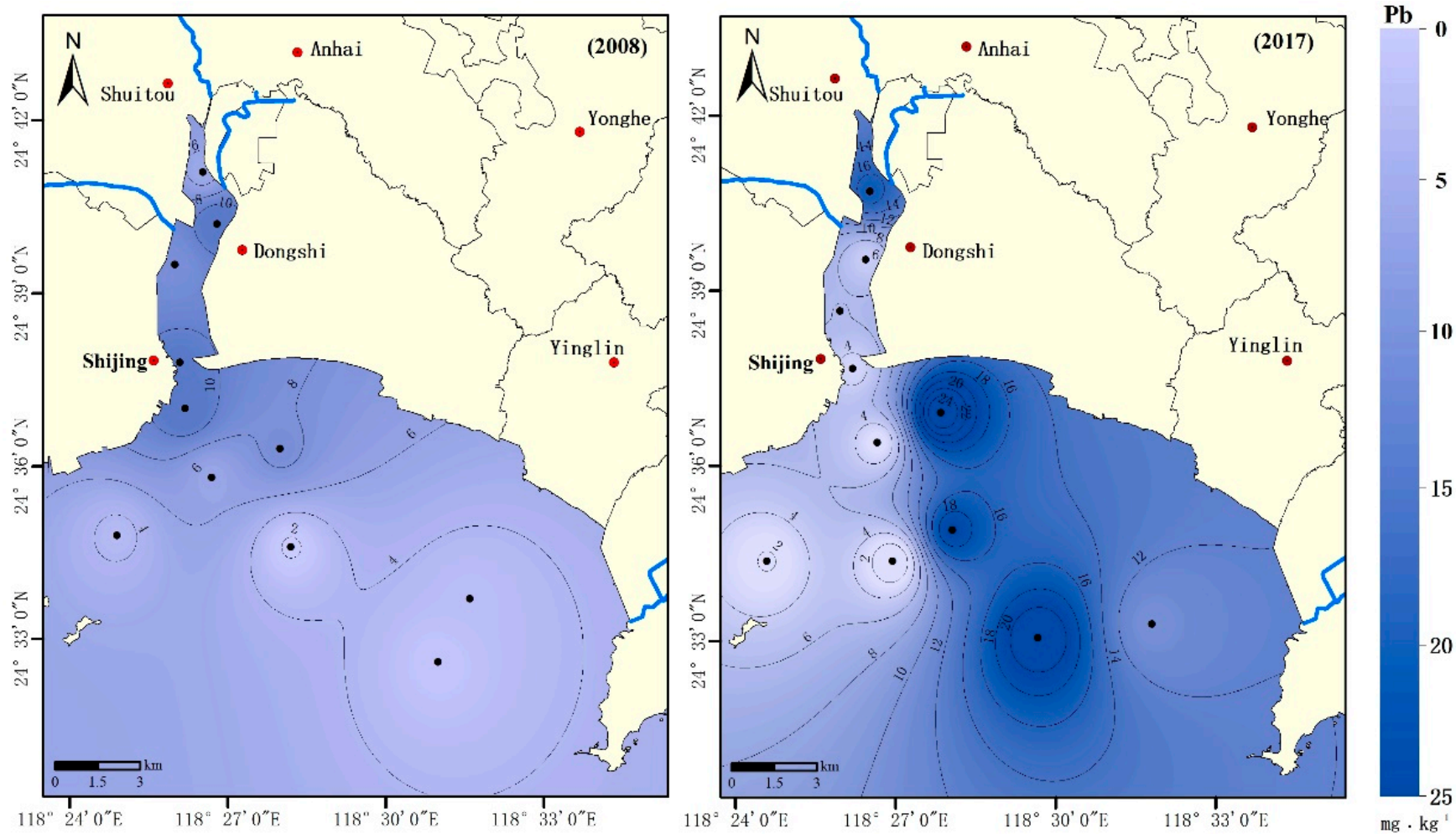

(b)

Figure 3. Cont. 

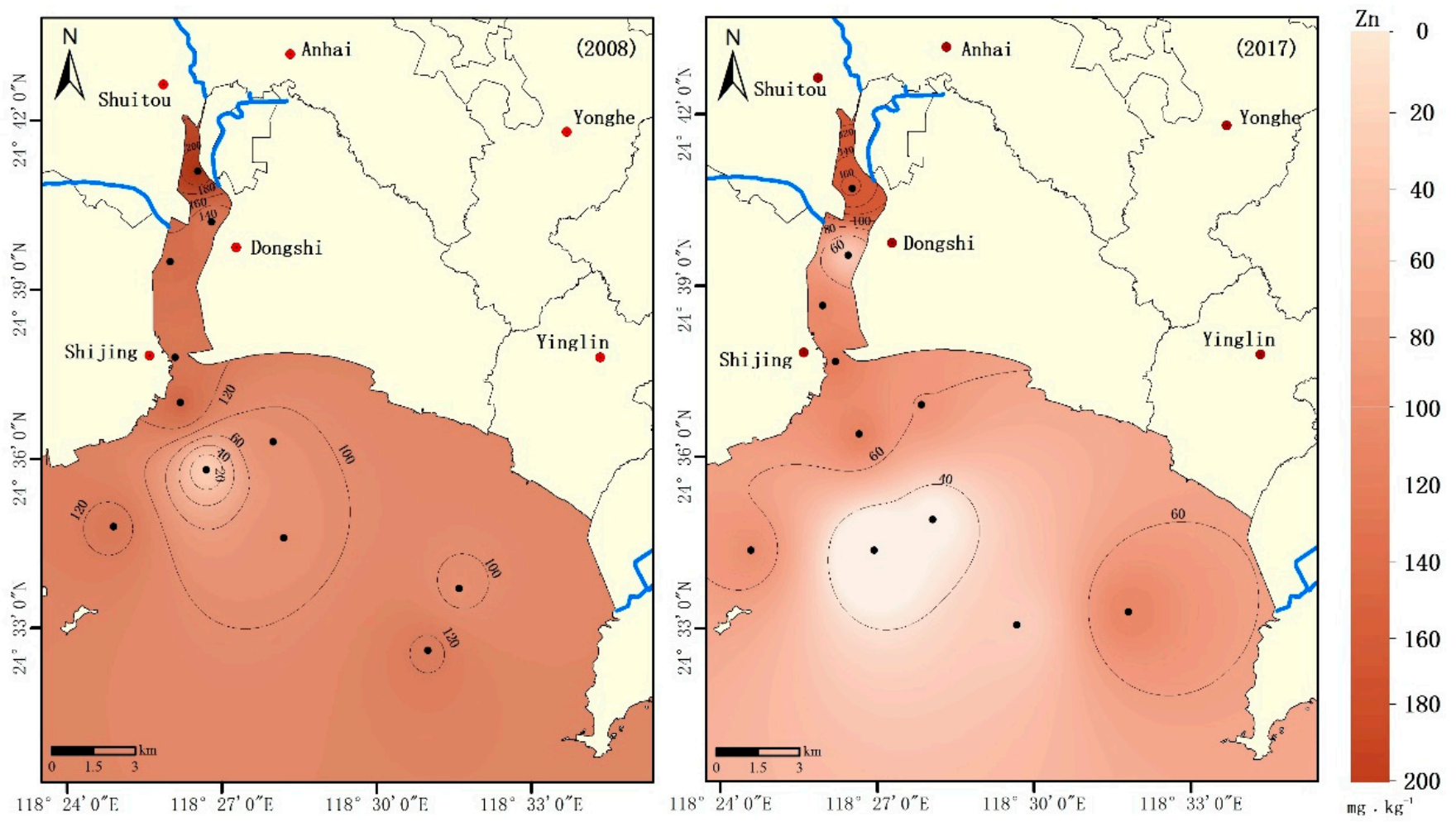

(c)
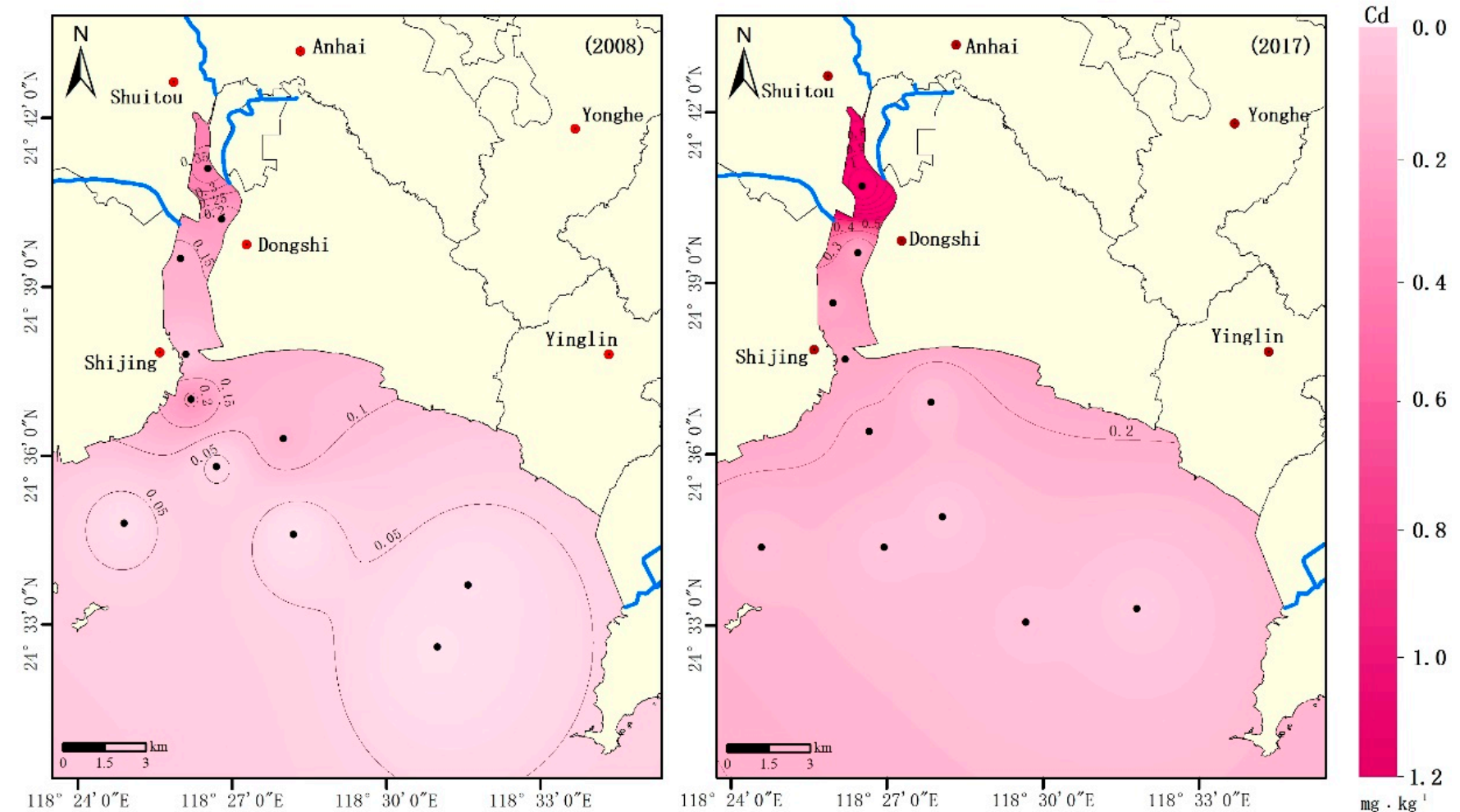

(d)

Figure 3. Cont. 

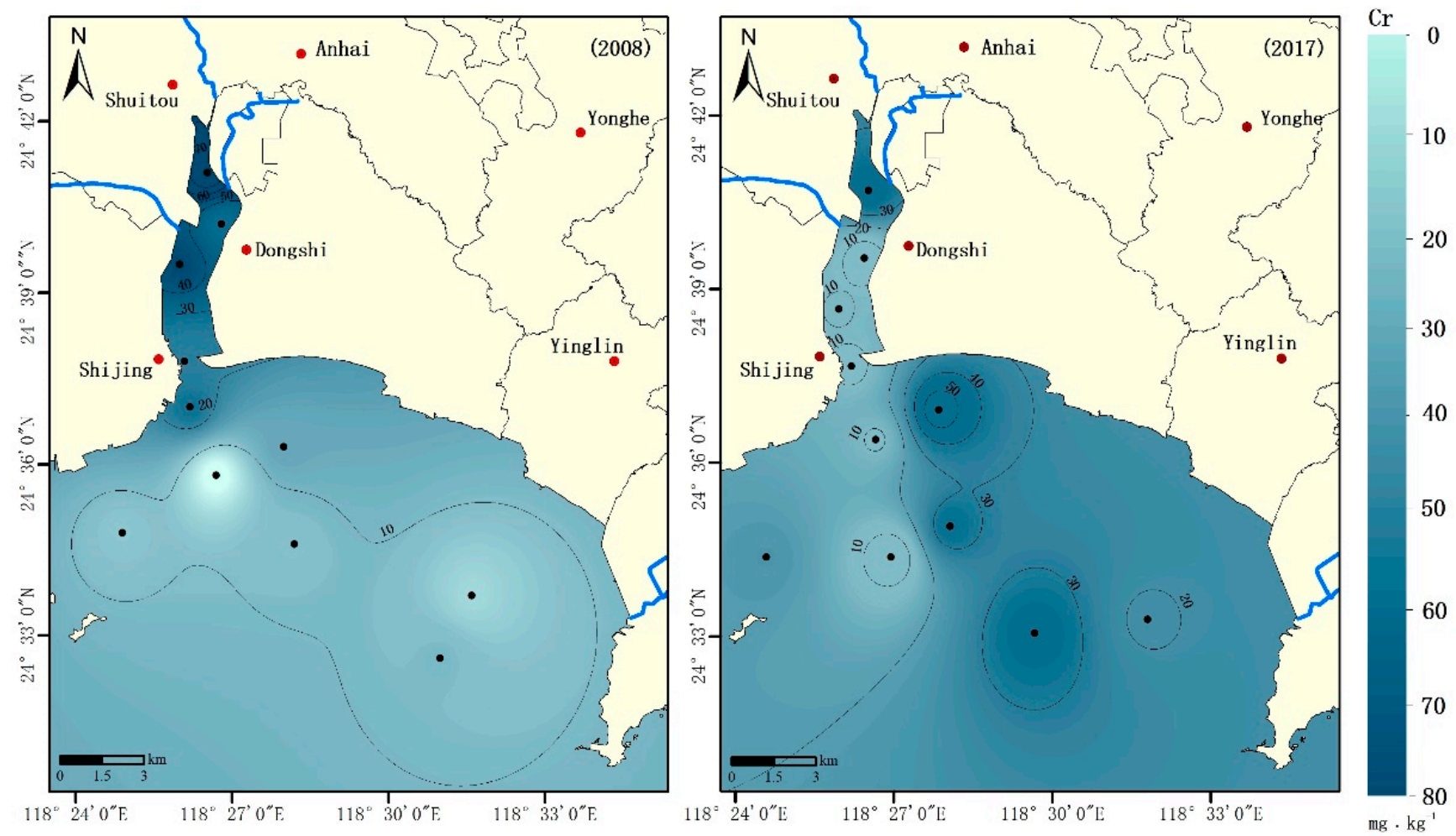

(e)
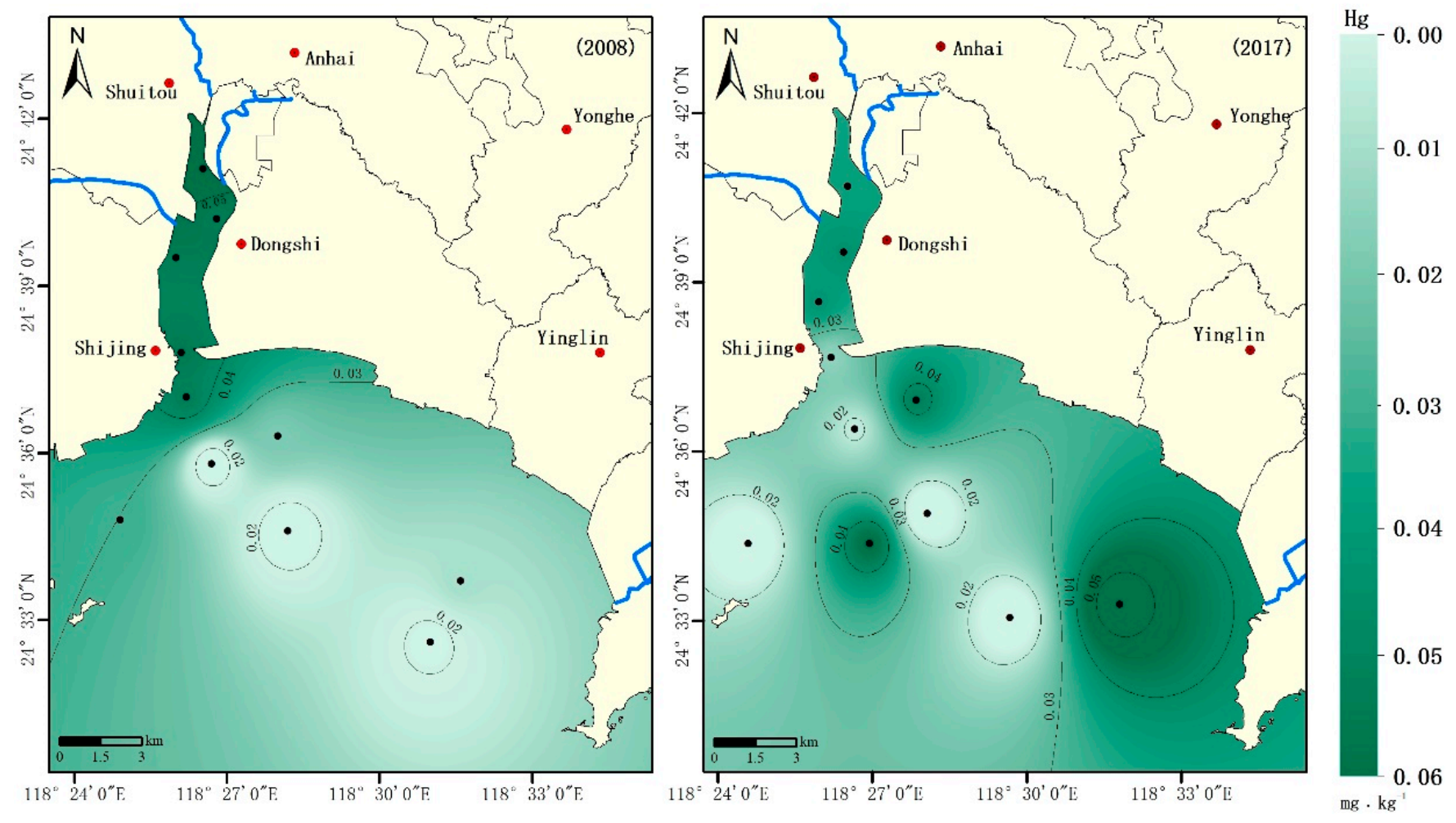

(f)

Figure 3. Cont. 


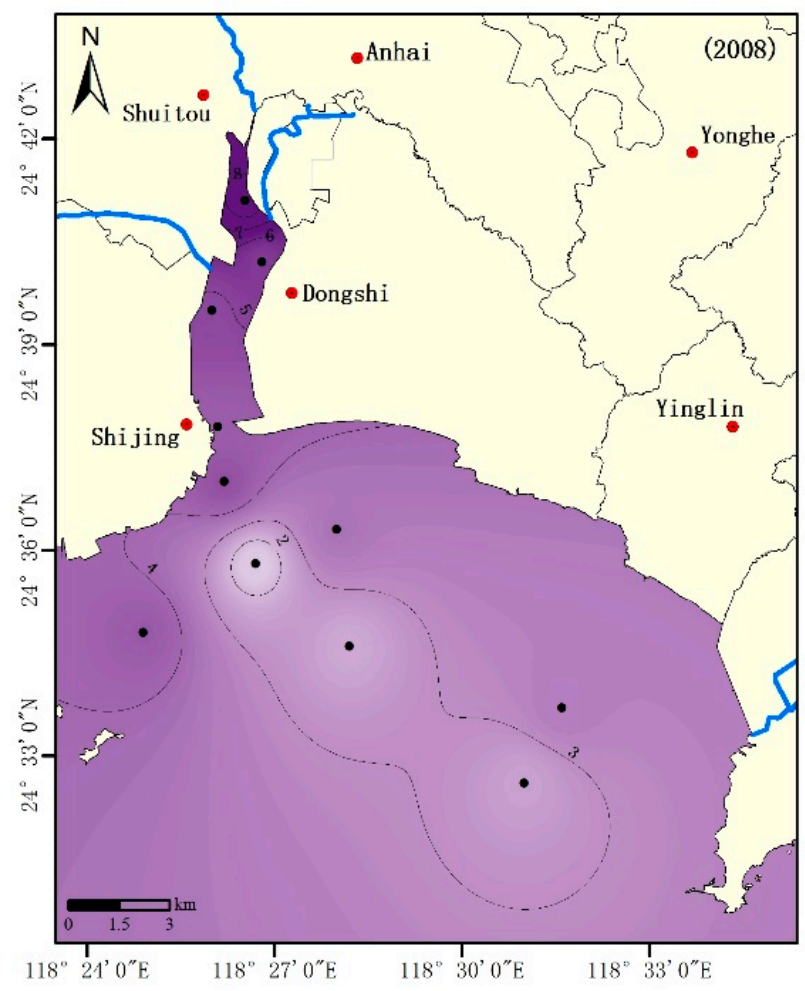

(g)

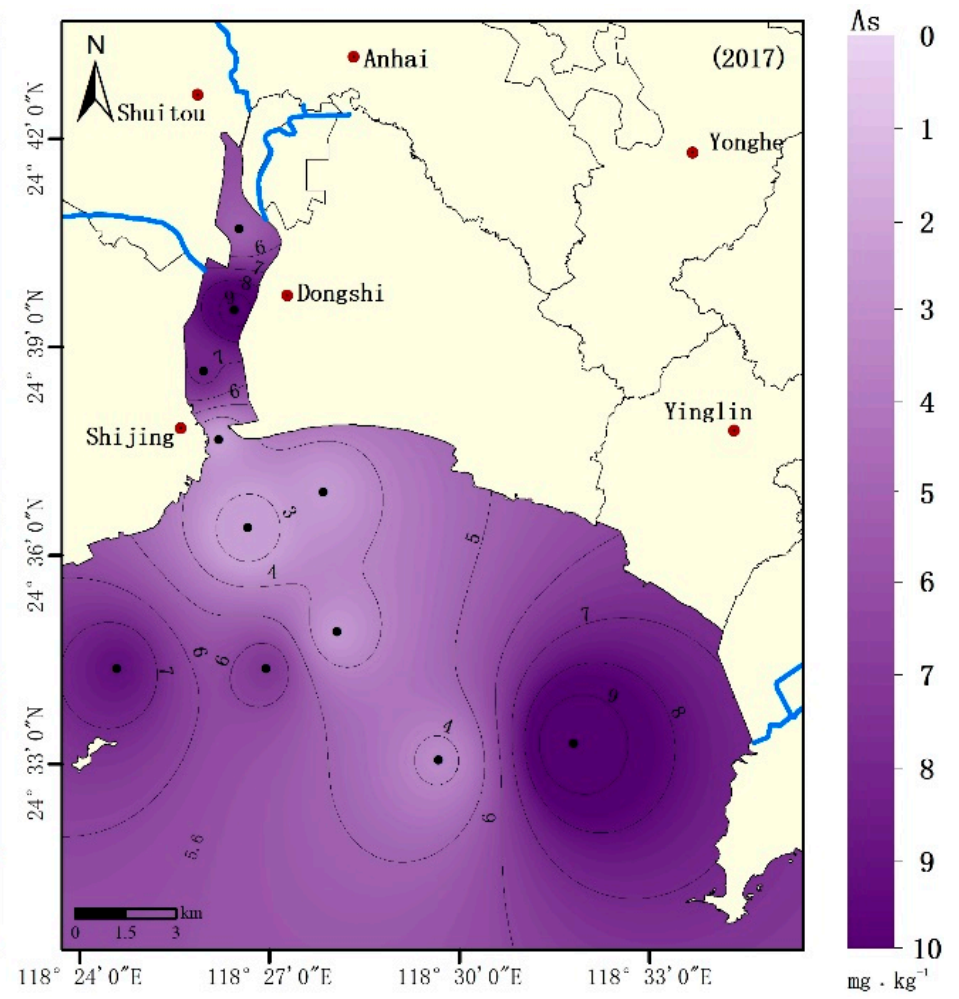

Figure 3. Spatial distributions of the heavy metals (a) $\mathrm{Cu},(\mathbf{b}) \mathrm{Pb},(\mathbf{c}) \mathrm{Zn},(\mathbf{d}) \mathrm{Cd},(\mathbf{e}) \mathrm{Cr},(\mathbf{f}) \mathrm{Hg}$, and (g) As concentrations in Weitou Bay surface sediment.

Before Pearson correlation analysis, the data were tested for normality. Only the data of five parameters (TOC, $\mathrm{Pb}, \mathrm{Zn}, \mathrm{Hg}$, and $\mathrm{As}$ ) had a normal distribution $(p>0.05)$. A log-transformation was applied to the other parameters (Sulfide, $\mathrm{Cu}, \mathrm{Cd}$, and $\mathrm{Cr}$ ) to satisfy the conditions for the statistical tests. Statistically, these independent variables have mutual relationships, which is suitable for PCA, with a Kaiser-Meyer-Olkin (KMO) value of 0.625 (>0.5) and a Bartlett's spherical test value of 0 .

Table 2 presents the results of the correlation analysis, indicating that $\mathrm{Cu}, \mathrm{Zn}, \mathrm{Cr}$, $\mathrm{Cd}$, and $\mathrm{Hg}$ have significant positive correlations with $\mathrm{TOC}$, and that $\mathrm{Cu}, \mathrm{Cr}, \mathrm{Cd}$, and $\mathrm{Hg}$ have significant positive correlations with sulfide. Chemical-specific surface adsorption, cation exchange reactions, and chelating reactions may play significant roles in the spatial distribution pattern of heavy metals in Weitou Bay. These reactions form metal organic complexes or precipitate metal sulfides, thereby promoting the migration of heavy metals from the water to the sediment. In a comparison of the ability of TOC and sulfides to control heavy metal distributions, Zn was more selectively absorbed by TOC than by sulfide. Moreover, $\mathrm{Cu}, \mathrm{Zn}$, and $\mathrm{Hg}$ had better correlations with TOC and sulfide. In contrast, $\mathrm{Cr}$ and $\mathrm{Cd}$ were more related to concentration by sulfide. There were significant correlations among $\mathrm{Cu}, \mathrm{Cd}$, and $\mathrm{Cr}$. In addition, $\mathrm{Cu}, \mathrm{Zn}$ and $\mathrm{Hg}$ had significant correlations, and there were remarkable correlations between $\mathrm{As}, \mathrm{Cd}$, and $\mathrm{Hg}$. The relatively high correlations among the heavy metals indicate that they likely shared the same pollution source, geochemical behaviors, and mobility pathways, or at least shared one main origin.

The results of the PCA (Table 3) indicate that the first three principal components accounted for $81.727 \%$ of the total variance, which may play an important role in explaining the potential pollution source and other factors affecting the distribution of heavy metals. The first principal component (PC1) accounted for $49.936 \%$ of the total variance, exhibiting high positive loads from TOC (0.826), sulfide (0.821), Cu (0.832), Zn (0.700), Cd (0.769), Cr (0.697), Hg (0.773), and As (0.499). PC1 may reflect an anthropogenic origin, including industrial waste, agricultural source pollutants, and urban domestic sewage, which are 
the major contributors of heavy metals to marine sediments [12]. The spatial distributions of heavy metals in Weitou Bay indicate that the high concentration areas are located near the river mouth (inner bay) and along the coast of a concentrated industrial area, which is consistent with the large number of riverside or coastal industries, including printing and dyeing factories, tanneries, and electroplating factories. Wastewater from printing and dyeing factories contains a variety of heavy metal pollutants, including $\mathrm{Cu}, \mathrm{Zn}, \mathrm{Cd}, \mathrm{Cr}$, and $\mathrm{Hg}$. Moreover, $\mathrm{Cr}, \mathrm{Zn}$, and $\mathrm{Cu}$ are commonly used in electroplating, and $\mathrm{Cr}$ is the main heavy metal pollutant in tanning facilities. Fertilizers and pesticides used for agriculture are generally the main sources of $\mathrm{As}$ and $\mathrm{Hg}$ [26-30]. In addition, the contributions from TOC and sulfide in PC1 reached 0.826 and 0.821 , respectively, which further supports a scenario where organic carbon and sulfide play important roles in metal ion complexing. The release of metal ions accompanied by organic matter degradation and the binding and fixation by sulfur ions are also important sources of heavy metals in sediments.

Table 2. Pearson correlation matrix for heavy metals, TOC, and sulfide in the surface sediment of Weitou Bay.

\begin{tabular}{ccccccccc}
\hline & TOC & Sulfide & $\mathbf{C u}$ & $\mathbf{P b}$ & $\mathbf{Z n}$ & $\mathbf{C d}$ & $\mathbf{C r}$ & $\mathbf{H g}$ \\
\hline TOC & 1 & & & & & & \\
Sulfide & $0.671^{* *}$ & 1 & & & & & & \\
$\mathrm{Cu}$ & $0.690^{* *}$ & $0.562^{* *}$ & 1 & & & & \\
$\mathrm{~Pb}$ & -0.053 & 0.293 & 0.013 & 1 & & & \\
$\mathrm{Zn}$ & $0.866^{* *}$ & 0.407 & $0.645^{* *}$ & -0.139 & 1 & & & \\
$\mathrm{Cd}$ & $0.465^{*}$ & $0.773^{* *}$ & $0.583^{* *}$ & 0.088 & 0.235 & 1 & & \\
$\mathrm{Cr}$ & $0.459^{*}$ & $0.556^{* *}$ & $0.449^{*}$ & $0.668^{* *}$ & 0.407 & $0.502^{*}$ & 1 & \\
$\mathrm{Hg}$ & $0.530^{*}$ & $0.497^{*}$ & $0.656^{* *}$ & 0.070 & $0.481^{*}$ & $0.487^{*}$ & 0.399 & 1 \\
$\mathrm{As}$ & 0.160 & 0.286 & 0.305 & -0.117 & 0.099 & $0.554^{* *}$ & 0.250 & $0.615^{* *}$ \\
\hline
\end{tabular}

Table 3. Results of the principal component analysis for heavy metals, TOC, and sulfide in the surface sediment of Weitou Bay.

\begin{tabular}{cccc}
\hline & PC1 & PC2 & PC3 \\
\hline TOC & 0.826 & -0.277 & -0.396 \\
Sulfide & 0.821 & 0.214 & 0.000 \\
$\mathrm{Cu}$ & 0.832 & -0.199 & -0.095 \\
$\mathrm{~Pb}$ & 0.183 & 0.931 & -0.164 \\
$\mathrm{Zn}$ & 0.700 & -0.395 & -0.503 \\
$\mathrm{Cd}$ & 0.769 & 0.116 & 0.389 \\
$\mathrm{Cr}$ & 0.697 & 0.583 & -0.150 \\
$\mathrm{Hg}$ & 0.773 & -0.142 & 0.271 \\
$\mathrm{As}$ & 0.499 & -0.120 & 0.771 \\
Eigenvalue & 4.494 & 1.573 & 1.288 \\
\% of variance & 49.936 & 17.483 & 14.308 \\
Cumulative $\%$ & 49.936 & 67.419 & 81.727 \\
\hline
\end{tabular}

The second principal component (PC2) explained $17.483 \%$ of the variance, with high contributions from $\mathrm{Pb}$ (0.931) and $\mathrm{Cr}$ (0.583). In this case, atmospheric deposition and precipitation were also significant factors that contributed to the sources of $\mathrm{Pb}$ and $\mathrm{Cr}$. Some studies have shown that urban transportation is the main source of $\mathrm{Pb}$ and $\mathrm{Cr}$, since alloy materials used in car bodies and yellow paint on road surfaces contain high concentrations of $\mathrm{Cr}$, and vehicle emissions contain considerable amounts of $\mathrm{Pb}[22,31] . \mathrm{Pb}$ in the environment is mainly derived from fossil fuel combustion [7]. After it is released through industrial combustion and automobile exhaust, $\mathrm{Pb}$ enters the water through atmospheric deposition and rainfall. In addition, port shipping is another important source of $\mathrm{Pb}$ in Weitou Bay. According to data from the annual Quanzhou City Statistics Bulletin on National Economic and Social Development, there were 0.33 million vehicles in Quanzhou in 2008, with a total annual port capacity of 72.24 million tons and a total social electricity 
consumption of 26.9 billion kWh. By 2017, the number of vehicles reached 1.35 million, the annual port throughput was 129.86 million tons, and the total social power consumption was 47.0 billion $\mathrm{kWh}$. These data indicate that the fossil fuel consumption in Quanzhou City increased from 2008 to 2017, which can lead to the doubling of Pb contents in the surface sediments of Weitou Bay, which is consistent with the data obtained in this study.

The third principal component (PC3) explained $14.308 \%$ of the variance, with the largest contribution from As, whose spatial variations were represented by relatively low RSDs among the studied metals. Moreover, the mean concentration of As was similar to the environmental background value. Based on the above analysis, PC3 indicates a natural source, such as rock weathering or erosion. In addition, the PC1 value was also highly correlated with As. From the results of the correlation analysis, As was significantly correlated with $\mathrm{Hg}$, which indicates that As in the Weitou Bay surface sediment is affected by both human activity and natural processes.

\subsection{Potential Ecological Risks of Heavy Metals}

The results of the potential ecological risk assessment are summarized in Table 4. In 2008 and 2017, the mean $E_{r}^{i}$ values exhibited decreasing orders of $\mathrm{Cd}(54.0)>\mathrm{Hg}(21.4)>$ $\mathrm{Cu}(8.6)>\mathrm{As}(6.5)>\mathrm{Zn}(1.4)>\mathrm{Pb}(0.9)$, and $\mathrm{Cd}(126.4)>\mathrm{Hg}$ (19.3) $>\mathrm{As}(8.8)>\mathrm{Cu}(3.4)$ $>\mathrm{Pb}(1.3)>\mathrm{Zn}(0.8)$, respectively. In both 2008 and 2017, Cd was the most harmful metal, followed by Hg. These two elements accounted for more than $80 \%$ of the comprehensive $R I$, indicating that they are the main potential ecological risk factors in Weitou Bay.

Table 4. Potential ecological risks for heavy metals in the surface sediment of Weitou Bay.

\begin{tabular}{|c|c|c|c|c|c|c|c|c|c|}
\hline \multirow{2}{*}{ Year } & \multirow{2}{*}{ Station } & \multicolumn{7}{|c|}{$E_{r}^{i}$} & \multirow{2}{*}{$R I$} \\
\hline & & $\mathrm{Cu}$ & $\mathbf{P b}$ & Zn & $\mathrm{Cd}$ & $\mathrm{Cr}$ & $\mathrm{Hg}$ & As & \\
\hline \multirow{8}{*}{2008} & Min & 0.8 & 0.2 & 0.3 & 7.8 & 0.1 & 10.8 & 2.0 & 27.0 \\
\hline & $\operatorname{Max}$ & 34.6 & 1.5 & 2.5 & 182.9 & 3.9 & 38.1 & 13.3 & 276.0 \\
\hline & Mean & 8.6 & 0.9 & 1.4 & 54.0 & 1.0 & 21.4 & 6.5 & 93.8 \\
\hline & Low risk (\%) & 100 & 100 & 100 & 55 & 100 & 100 & 100 & 82 \\
\hline & Moderate risk (\%) & 0 & 0 & 0 & 18 & 0 & 0 & 0 & 18 \\
\hline & Considerable risk (\%) & 0 & 0 & 0 & 18 & 0 & 0 & 0 & 0 \\
\hline & Very high risk (\%) & 0 & 0 & 0 & 9 & 0 & 0 & 0 & 0 \\
\hline & Disastrous risk (\%) & 0 & 0 & 0 & 0 & 0 & 0 & 0 & / \\
\hline \multirow{8}{*}{2017} & Min & 0.7 & 0.0 & 0.2 & 58.6 & 0.3 & 7.6 & 3.3 & 78.8 \\
\hline & $\operatorname{Max}$ & 14.0 & 3.4 & 1.9 & 561.9 & 2.8 & 34.3 & 15.7 & 612.2 \\
\hline & Mean & 3.4 & 1.3 & 0.8 & 126.4 & 1.1 & 19.3 & 8.8 & 161.0 \\
\hline & Low risk (\%) & 100.0 & 100.0 & 100.0 & 0.0 & 100.0 & 100.0 & 100.0 & 73 \\
\hline & Moderate risk (\%) & 0 & 0 & 0 & 55 & 0 & 0 & 0 & 18 \\
\hline & Considerable risk (\%) & 0 & 0 & 0 & 36 & 0 & 0 & 0 & 0 \\
\hline & Very high risk $(\%)$ & 0 & 0 & 0 & 0 & 0 & 0 & 0 & 9 \\
\hline & Disastrous risk (\%) & 0 & 0 & 0 & 9 & 0 & 0 & 0 & / \\
\hline
\end{tabular}

"/" indicates no available comparison classification.

The individual element potential ecological risk indices indicate that, in Weitou Bay, the $E_{r}^{i}$ values of most of the heavy metals were less than 40 , reflecting an overall low ecological risk status, except for $\mathrm{Cd}$. The $E_{r}^{i}$ contribution rates to the $R I$ by $\mathrm{Cd}$ in 2008 and 2017 were $57.6 \%$ and $78.5 \%$, respectively, which were significantly higher than those of the other heavy metals. The maximum $E_{r}^{i}$ value for Cd increased from 182.9 (2008) to 561.9 (2017), indicating that the potential ecological risk for Cd increased from 'very high' to 'disastrous'.

The spatial distribution of $R I$ values generally decreased from north to south due to the intense industrial and other human activities located along the coast of the inner bay (Figure 4). Even with 10 years of economic development, the RI only increased significantly in the inner bay. In 2008, $18 \%$ of the sampling sites had moderate ecological risks (mostly in the inner bay), while the others had low ecological risks. The situation was worse in 
2017 , with $18 \%$ of the sampling sites having moderate ecological risks and $9 \%$ having very high ecological risks due to Cd pollution. As shown in Table 3, PC1 $(49.936 \%$ of the total variance) had a high contribution from $\mathrm{Cd}(0.769)$, indicating that anthropogenic origins are the major source of $\mathrm{Cd}$ pollution. Since there are many factories that emit heavy metal pollutants, reducing industrial pollution should attract special attention for mitigating pollution and increasing ecological restoration in Weitou Bay.
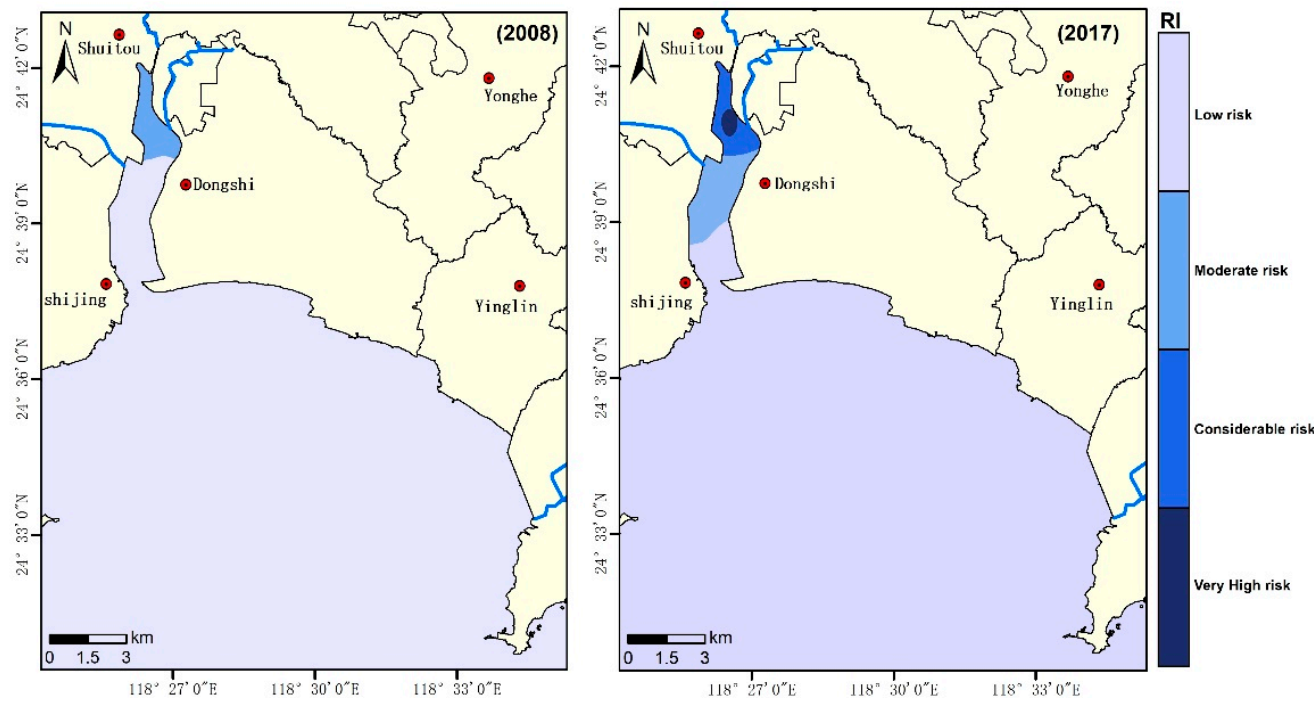

Figure 4. Spatial distribution of $R I$ in Weitou Bay.

\section{Conclusions}

Based on the concentrations of TOC, sulfides, and heavy metals in the surface sediment samples collected from Weitou Bay in 2008 and 2017, we analyzed the spatiotemporal variations in heavy metal contents in the surface sediment and further assessed the pollution sources and potential ecological risks. High concentrations of pollutants were generally located near the river mouths (inner bay) and along the coast of the industrial area and shifted from the inner bay to the outer bay from 2008 to 2017. This indicates that heavy metals are associated with anthropogenic activity and hydrodynamic conditions in the bay. The average heavy metal concentrations were lower than their background values, except those of $\mathrm{Cu}, \mathrm{Zn}$, and $\mathrm{Cd}$ in 2008 and that of $\mathrm{Cd}$ in 2017.

Multivariate analyses indicate that $\mathrm{Cu}, \mathrm{Zn}, \mathrm{Cd}, \mathrm{Cr}$, and $\mathrm{Hg}$ were mainly derived from industrial pollution, $\mathrm{Pb}$ predominantly originated from traffic emissions and industrial combustion, and agricultural activity and natural processes were the major sources of As. Moreover, physicochemical interactions with organic matter and sulfide may play significant roles in the distribution of heavy metals in Weitou Bay.

In general, Weitou Bay suffers from low to moderate heavy metal ecological risk, except for a small region that suffers from very high risk. From 2008 to 2017, the potential ecological risk of heavy metals in the surface sediments increased in the inner of Weitou Bay, which should be treated as the prior ecological protection areas. $\mathrm{Cd}$ was a large contributor ( $57.6 \%$ and $78.5 \%$ in 2008 and 2017, respectively) to the RI, and was the most serious of the polluting metals in the 2017 sediment samples, followed by Hg.

Long-term heavy metal monitoring, particularly of $\mathrm{Cd}$ and $\mathrm{Hg}$, should be conducted to obtain real-time tracking of potential ecological risks in this region. Controlling industrial effluent discharge is the most effective measure for improving the marine environment. Overall, this study provides important guidance for pollution control measures and ecological restoration in Weitou Bay. 
Author Contributions: Conceptualization, Q.C. and F.H.; data curation, Q.C.; formal analysis, Q.C.; funding acquisition, F.H.; investigation, Q.C.; methodology, Q.C. and A.C.; project administration, F.H.; software, Q.C. and A.C.; supervision, Q.C. and F.H.; validation, A.C.; visualization, A.C.; writing—original draft, Q.C. and A.C.; writing—review and editing, F.H. All authors have read and agreed to the published version of the manuscript.

Funding: This research was supported by a project sponsored by the Scientific Research Foundation of the Third Institute of Oceanography, Ministry of Natural Resources, China (No. 2017016).

Institutional Review Board Statement: Not applicable.

Informed Consent Statement: Not applicable.

Acknowledgments: This research was supported by a project sponsored by the Scientific Research Foundation of the Third Institute of Oceanography, Ministry of Natural Resources, China (No. 2017016). The authors are grateful to Yuanbiao Zhang, Hui Lin, Weili Wang and for their assistance with field sampling and laboratory analysis.

Conflicts of Interest: The authors declare no conflict of interest.

\section{References}

1. Li, Q.; Wu, Z.; Chu, B.; Zhang, N.; Cai, S.; Fang, J. Heavy metals in coastal wetland sediments of the Pearl River Estuary, China. Environ. Pollut. 2007, 149, 158-164. [CrossRef]

2. Qiu, Y.W. Bioaccumulation of heavy metals both in wild and mariculture food chains in Daya Bay, South China. Estuar. Coast. Shelf Sci. 2015, 163, 7-14. [CrossRef]

3. Yi, Y.; Yang, Z.; Zhang, S. Ecological risk assessment of heavy metals in sediment and human health risk assessment of heavy metals in fishes in the middle and lower reaches of the Yangtze River basin. Environ. Pollut. 2011, 159, 2575-2585. [CrossRef]

4. Pan, K.; Wang, W.X. Trace metal contamination in estuarine and coastal environments in China. Sci. Total Environ. 2012, 421-422, 3-16. [CrossRef]

5. Gui, D.; Yu, R.Q.; Karczmarski, L.; Ding, Y.L.; Zhang, H.F.; Sun, Y.; Zhang, M.; Wu, Y.P. Spatiotemporal trends of heavy metals in Indo-Pacific humpback dolphins (Sousa chinensis) from the western Pearl River estuary, China. Environ. Sci. Technol. 2017, 51, 1848-1858. [CrossRef] [PubMed]

6. Aa, D.S.M.; Spencer, K.; Kloas, W.; Toffolon, M.; Zarfl, C. Metal fate and effects in estuaries: A review and conceptual model for better understanding of toxicity. Sci. Total Environ. 2016, 541, 268-281.

7. Christophoridis, C.; Bourliva, A.; Evgenakis, E.; Papadopoulou, L.; Fytianosa, K. Effects of anthropogenic activities on the levels of heavy metals in marine surface sediments of the Thessaloniki Bay, Northern Greece: Spatial distribution, sources and contamination assessment. Microchem. J. 2019, 145, 104001. [CrossRef]

8. Ali, M.M.; Ali, M.L.; Islam, M.S.; Rahman, M.Z. Preliminary assessment of heavy metals in water and sediment of Karnaphuli River, Bangladesh. Environ. Nanotechnol. Monit. Manag. 2016, 5, 27-35. [CrossRef]

9. Statistics Bureau of Quanzhou City (China). Statistical Bulletin of National Economic and Social Development of Quanzhou City in 2008. Available online: http:/ / www.tjcn.org/tjgb/13fj/1629.html. (accessed on 19 March 2009). (In Chinese).

10. Statistics Bureau of Quanzhou City (China). Statistical Bulletin of National Economic and Social Development of Quanzhou City in 2017. Available online: http:/ / www.tjcn.org/tjgb/13fj/35382.html. (accessed on 29 March 2018). (In Chinese).

11. Xiong, H.; Yang, L.H.; Deng, Y.Z. Heavy metals distribution and potential ecological risk assessment on surface sediments of Anhai Bay and Weitou Bay, Fujian. J. App. Oceanogr. 2019, 38, 68-74. (In Chinese)

12. Hu, G.R.; Yu, R.L. A preliminary study on Anhai Gulf in Quanzhou sediments contamination and control measurement. J. Fujian Norm. Univ. Natur. Sci. Ed. 2005, 21, 43-47. (In Chinese)

13. Wang, J.; Chen, L. Nutrient distribution and eutrophication in seawater of Anhai Bay, Fujian, Quanzhou. Mar. Envrion. Sci. 2011, 30, 525-527. (In Chinese)

14. Zhu, J.H.; Meng, Y.Q.; Tong, C.F.; Shi, J. Mechanism of suspended sediment transport in Weitou Bay in Fujian. J. Waterw. Harb. 2016, 37, 121-127. (In Chinese)

15. Xu, C.L. Discussion on embank construction of erosion zone in northern bank of Weitou Bay. Hydraul. Sci. Technol. 2008, 1, 46. (In Chinese)

16. Lu, Z.B.; Du, Q.; Qian, X.M.; Cai, Q.H.; Xu, C.Y.; Fang, M.J. Carrying capacity of shellfish culture in Weitou Bay of Fujian. S. China Fish. Sci. 2006, 6, 31-38. (In Chinese)

17. Liu, J.H.; Lin, H.S.; Wang, J.J.; He, X.B.; Huang, Y.Q.; Zheng, F.W.; Li, R.G.; Zheng, C.X.; Jiang, J.X. Changes of macrobenthic community structure in Anhai Bay and its adjacent sea in spring of recent years. J. Appl. Oceanogr. 2015, 34, 227-234. (In Chinese)

18. SOA (State Oceanic Administration of China). Specification for Marine Monitoring of China: GB17378.5-2007; Standards Press of China: Beijing, China, 2007. (In Chinese)

19. Hakanson, L. An ecological risk index for aquatic pollution control. A sedimentological approach. Water Res. 1980, 14, 975-1001. [CrossRef] 
20. Liu, Y.Q. Study and application of the soil environmental background values in Fujian Coastal Zone. Mar. Environ. Sci. 1995, 14, 68-73. (In Chinese)

21. Madiseh, S.D.; Savary, A.; Parham, H.; Sabzalizadeh, S. Determination of the level of contamination in Khuzestan coastal waters (Northern Persian Gulf) by using an ecological risk index. Environ. Monit. Assess 2009, 159, 521-530. [CrossRef] [PubMed]

22. Zhao, B.F.; Wang, X.M.; Jin, H.B.; Feng, H.; Shen, G.; Cao, Y.; Yu, C.; Lu, Z.; Zhang, Q. Spatiotemporal variation and potential risks of seven heavy metals in seawater, sediment, and seafood in Xiangshan Bay, China (2011-2016). Chemosphere 2018, 212, 1163-1171. [CrossRef]

23. Zhou, S.Y.; Kang, R.; Ji, C.R.; Kauffman, H. Heavy metal distribution, contamination and analysis of sources-Intertidal zones of Sandu Bay, Ningde, China. Mar. Pollut. Bull. 2018, 135, 1138-1144. [CrossRef] [PubMed]

24. Ding, X.G.; Ye, S.Y.; Yuan, H.M.; Krauss, K.W. Spatial distribution and ecological risk assessment of heavy metals in coastal surface sediments in the Hebei Province offshore area, Bohai Sea, China. Mar. Pollut. Bull. 2018, 131, 655-661. [CrossRef]

25. Zhang, M.; He, P.; Qiao, G.; Huang, J.; Yuan, X.; Li, Q. Heavy metal contamination assessment of surface sediments of the Subei Shoal, China: Spatial distribution, source apportionment and ecological risk. Chemosphere 2019, 223, 211-222. [CrossRef]

26. Wang, H.J.; Ye, S.Y.; Du, Y.S.; Li, S.Q.; Zhu, A.M. The distribution and compare study of surface sediment in eastern Jiaozhou Bay and Qingdao adjacent coastal sea. Trans. Oceanol. Limnol. 2007, 4, 80-86. (In Chinese)

27. Lv, J.S.; Liu, Y.; Zhang, Z.L.; Dai, J.R. Factorial kriging and stepwise regression approach to identify environmental factors influencing spatial multi-scale variability of heavy metals in soils. J. Hazard. Mater. 2013, 261, 387-397. [CrossRef]

28. Martín, J.A.R.; Arias, M.L.; Corbí, J.M.G. Heavy metals contents in agricultural topsoils in the Ebro basin (Spain). Application of the multivariate geoestatistical methods to study spatial variations. Environ. Pollut. 2006, 144, 1001-1012. [CrossRef]

29. Chen, S.T.; Miao, A.X.; Wen, T.T.; Yang, X.H.; Zhu, Z.X. Heavy metals in the surface sediment of Liaodong bay and their potential ecological risk. Mar. Environ. Sci. 2019, 38, 256-262. (In Chinese)

30. Zhang, M.; Wang, X.P.; Liu, C.; Lu, J.Y.; Qin, Y.H.; Mo, Y.K.; Xiao, P.J.; Liu, Y. Quantitative source identification and apportionment of heavy metals under two different land use types: Comparison of two receptor models APCS-MLR and PMF. Environ. Sci. Pollut. Res. Int. 2020, 27, 42996-43010. [CrossRef] [PubMed]

31. Shi, W.C.; Gu, Z.G.; Feng, Y.; Wu, Y.N.; Wu, X.R.; Zhang, Z.S. Source apportionment of heavy metals in sediments with application of APCS-MLR model in Baoxiang River. Environ. Sci. Technol. 2020, 43, 51-59. (In Chinese) 